Imágenes en Medicina Intensiva

\title{
Taponamiento cardíaco por derrame pericárdico masivo secundario a hipotiroidismo primario
}

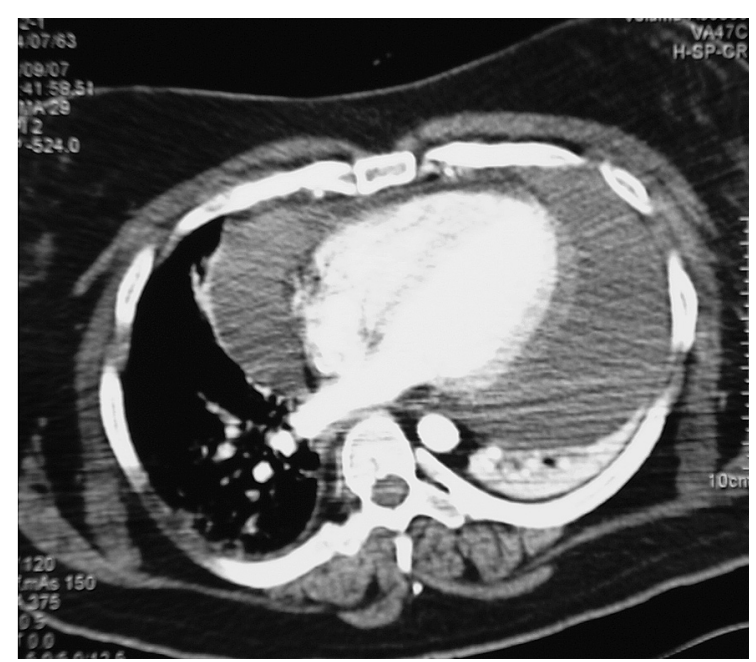

Figura 1. Derrame pericárdico severo.

Presentamos un caso de una paciente de 44 años con síndrome de Down que acude a urgencias por cuadro de disnea progresiva de 2 meses de evolución, hasta hacerse de reposo, y aumento del perímetro abdominal. Analíticamente se objetiva: TSH, $18.890 \mu \mathrm{U} / \mathrm{ml}$ y T4L: $<0,15 \mathrm{ng} / \mathrm{dl}$. El ecocadiograma muestra derrame pericárdico severo con signos de compromiso hemodinámico y colapso de cavidades derechas confirmado posteriormente con tomografía computarizada toracoabdominal con contraste. En la UCI se realiza pericardiocentesis y evacuación de $2.400 \mathrm{ml}$ de líquido seroso; los estudios bioquímicos, serológicos, microbiológicos y de inmunidad son negativos. Se comienza tratamiento sustitutivo con levotiroxina con buena evolución posterior. 